\title{
Implementasi Metode Pembelajaran Student Centered Learning (SCL) pada Mata Kuliah Asuhan Kebidanan Ibu Nifas di STIKes Maharani Malang
}

\author{
Nanik Susanti, Moch Agus Krisno Budiyanto, Mohamad Syahri , Ratna Diana F \\ STIKes Maharani Malang \\ email: naniksusanti@gmail.com
}

\begin{abstract}
Abstrak
Penelitian ini bertujuan untuk mengetahui implementasi metode pembelajaran Student Centered Learning (SCL) pada mata kuliah asuhan kebidanan ibu nifas di program studi kebidanan STIKes Maharani Malang. Pendekatan penelitian yang digunakan adalah kualitatif dengan menggunakan metode deskriptif melalui wawancara, observasi dan studi dokumen. Keabsahan data dalam penelitian menggunakan tehnik triangulasi sumber data. Hasil penelitian menunjukkan bahwa dalam perencanaan pembelajaran disusun RPS (Rencana Pelaksanaan Pembelajaran), dalam tahap pelaksanaan proses pembelajaran sudah diterapkan sesuai dengan silabus dan metode yang digunakan dalam pembelajaran asuhan kebidanan ibu nifas adalah menggunakan metode ceramah (CTJ) untuk menjelaskan materi konsep dasar dan menerapkan metode pembelajaran Student Centered Learning (SCL) seperti metode Small Group Discussion, Role play, Problem Based Learning dan demonstrasi. Pada tahap evaluasi pembelajaran dilakukan penilaian dalam bentuk tes tertulis, penilaian praktikum dan penilaian penugasan. Dengan menerapkan metode pembelajaran Student Centered Learning (SCL) mahasiswa lebih aktif dan mandiri dalam mengikuti proses belajar mengajar baik di kelas maupun di laboratorium dan hasil prestasi akademik mahasiswa rata-rata baik dengan mendapatkan nilai dalam kategori A dan B. Secara teknis tidak ditemukan kendala dalam pelaksanaan penerapan metode pembelajaran Student Centered Learning (SCL). Kata Kunci: Implementasi, Metode Student Centered Learning, Asuhan Ibu Nifas
\end{abstract}

\begin{abstract}
The research purpose is finding out about Student Centered Learning (SCL) Learning Method Implementation in Maternal Nursing Midwifery Subject in Midwifery Study Program in STIKes Maharani of Malang. Research approach used is qualitative by using descriptive method through interview, observation, and document study. Data validity in research uses data source triangulation technique. Research shows that in learning plan, RPS (Learning Application Plan) is managed, in learning process application, it has applied as syllable and method used in maternal nursing by using lecture method (CTJ) to explain basic concept material and apply Student Centered Learning (SCL) learning method just like Small Group Discussion, Role play, Problem Based Learning methods and demonstration. In learning evaluation, it's done through written test, practice assessment, and assignment assessment. By applying Student Centered Learning (SCL) learning method, students would be active and independent in following teaching and learning whether in class or laboratory, and academic achievement of the students averagely good based on points they got in category $A$ and $B$. Technically there's no obstacle in application of Student Centered Learning (SCL) learning method.
\end{abstract}

Keywords : Implementation, Student Centered Learning method, Maternal Nursing

\section{Pendahuluan}

Usaha untuk mengedepankan nilai-nilai kemanusiaan dalam pendidikan melahirkan kembali pendekatan pendidikan yang mementingkan pengembangan kreativitas dan kepribadian anak, ini merupakan gerakan humanisasi dalam proses pendidikan. Gerakan humanisasi ini meminta reformasi yang mendasar dalam pendidikan baik dalam metodologi belajar mengajar sampai kepada manajemen dan perencanaan pendidikan.

Perubahan paradigma dalam proses pembelajaran yang awalnya Teacher Centered Learning (TCL) menjadi Student Centered Learning (SCL) yang tertuang dalam Peraturan Menteri Riset, Teknologi dan Pendidikan Tinggi Republik Indonesia Nomor 44 Tahun 2015 Tentang Standar Nasional Pendidikan Tinggi Pasal 14. Implementasi proses pembelajaran sebagaimana tertuang pada Pasal 11 tentang Standar Proses Pembelajaran.

Hasil penelitian oleh Yahya Dwitama, 2014 : "Hasil korelasi antara penerapan metode pembelajaran SCL terhadap tingkat motivasi belajar mahasiswa didapatkan nilai $r=0,310$ dengan nilai $p=0,001 \quad(<0,05)$ yang artinya terdapat korelasi positif antara penerapan metode pembelajaran Student Centered Learning (SCL) terhadap tingkat motivasi belajar mahasiswa di Prodi S1 Fisioterapi Profesi Fakultas Kedokteran Universitas Hasanuddin Makassar.

Dalam Program Studi Diploma III Kebidanan ada beberapa mata kuliah berkarya yang membutuhkan ketrampilan yang kompeten dari mahasiswa, salah satu mata kuliah tersebut adalah mata kuliah asuhan kebidanan ibu nifas. Untuk mencapai kompetensi mahasiswa maka dalam 
memberikan pembelajaran asuhan kebidanan ibu nifas membutuhkan beberapa metode pembelajaran yang berpusat pada mahasiswa, yang mana mahasiswa dituntut lebih aktif dan mandiri. Dengan adanya perubahan metode pembelajaran yang berpusat pada mahasiswa, maka dalam penyusunan rencana pembelajaran perlu di evaluasi dalam pelaksanaannya.

Berdasarkan latar belakang diatas maka peneliti tertarik untuk melakukan penelitian dengan judul "Analisis Implementasi Metode Pembelajaran Student Centered Learning (SCL) Pada Mata Kuliah Asuhan Kebidanan Ibu Nifas di Program Studi Kebidanan STIKes Maharani Malang". Berkaitan dengan fenomena tersebut maka rumusan masalah dalam penelitian ini adalah : (1) Bagaimana perencanaan metode pembelajaran Student Centered Learning (SCL) pada mata kuliah asuhan kebidanan ibu nifas di Program Studi Kebidanan STIKes Maharani Malang?, (2) Bagaimana pelaksanaan penerapan metode pembelajaran Student Centered Learning (SCL) pada mata kuliah asuhan kebidanan ibu nifas di Program Studi Kebidanan STIKes Maharani Malang? Bagaimana evaluasi penerapan metode pembelajaran Student Centered Learning (SCL) pada mata kuliah asuhan kebidanan ibu nifas di Program Studi Kebidanan STIKes Maharani Malang?

\section{Metode Penelitian}

Penelitian ini dilakukan dengan menggunakan pendekatan kualitatif. Penelitian kualitatif adalah penelitian yang bermaksud untuk memahami fenomena tentang apa yang dialami oleh subjek penelitian secara holistik dan dengan deskripsi dalam bentuk kata-kata dan bahasa, pada suatu konteks khusus yang alamiah dan dengan memanfaatkan berbagai metode ilmiah.

Dalam penelitian ini mendeskripsikan temuan-temuan dari sasaran penelitian. Melalui pendekatan ini diharapkan dapat menghasilkan data yang bersifat deskriptif guna mengungkap dan memahami fenomena di lapangan, sehingga peneliti mampu mendeskripsikan, menguraikan dan menggambarkan penelitian tentang implementasi metode pembelajaran Student Centered Learning (SCL) pada mata kuliah Asuhan Kebidanan Ibu Nifas di Program Studi Diploma III Kebidanan STIKes Maharani Malang.

Lokasi penelitian adalah STIKes Maharani Malang Program Studi Kebidanan. Dasar pertimbangan peneliti adalah Program Studi Kebidanan STIKes Maharani Malang merupakan pendidikan vokasional. Sumber data dalam penelitian ini adalah kata-kata dan tindakan selebihnya adalah data tambahan seperti dokumen dan lain-lain.

Pengumpulan data dilakukan dengan menggunakan metode, wawancara, observasi dan studi dokumen untuk mengungkap data dan informasi tentang implementasi metode pembelajaran Student Centered Learning (SCL) pada mata kuliah asuhan kebidanan Ibu nifas di Program Studi Diploma III Kebidanan STIKes Maharani Malang.

Teknik analisis data yang digunakan dalam penelitian ini adalah analisis data kualitatif mengikuti konsep dari Miles and Huberman dan Spradley.Miles dan Huberman (1984) mengemukakan bahwa aktivitas dalam analisis data kualitatif dilakukan secara interaktif dan berlangsung secara terus menerus pada setiap tahapan penelitian hingga tuntas, hingga data jenuh. Aktivitas dalam analisis data yaitu data reduction, data display and conclution drawing/verivication.

Teknik Pemeriksaan Keabsahan Data mengemukakan bahwa pengecekan keabsahan data dilakukan dengan menggunakan: (1) Derajat kepercayaan (credibility) yaitu Triangulasi, (2) Validitas eksternal, (3) Kebergantungan (dependability), (4) Kepastian (confirmability).

Teknik keabsahan data yang akan digunakan oleh peneliti yaitu Triangulasi sumber data, uji kredibilitas data dilakukan dengan cara mengecek data yang telah diperoleh melalui beberapa sumber data yaitu melalui wawancara, observasi lapangan dan studi dokumentasi.

\section{Hasil Dan Pembahasan}

Hasil penelitian dan Pembahasan tentang perencanaan metode pembelajaran Student Centered Learning (SCL) pada Mata Kuliah Asuhan Kebidanan Ibu Nifas di Program Studi Kebidanan STIKes Maharani Malang,yaitu:

Ada 3 (tiga) hal temuan pada tahap perencanaan yaitu:

1. Pada tahap perencanaan pembelajaran diwujudkan dalam bentuk RPS (Rencana Pembelajaran Semester).

2. Metode pembelajaran yang digunakan dalam mata kuliah asuhan kebidanan nifas sudah sesuai dengan metode pembelajaran Student Centered Learning (SCL).

3. Penyusunan RPP (Rencana Pelaksanaan Pembelajaran) pada setiap pertemuan.

Penyusunan perencanaan pembelajaran yang telah di lakukan oleh dosen PJMK mata kuliah asuhan kebidanan ibu nifas dalam menyusun 
RPS (Rencana Pembelajaran Semester) dan RPP (Rencana Pelaksanaan Pembelajaran) sebagaimana tercantum dalam Peraturan Menteri Riset, Teknologi Dan Pendidikan Tinggi Republik Indonesia Nomor 44 Tahun 2015 Tentang Standar Nasional Pendidikan Tinggi pasal 12 yaitu:

(1) Perencanaan proses pembelajaran sebagaimana dimaksud dalam Pasal 10 ayat (2) huruf (b) disusun untuk setiap mata kuliah dan disajikan dalam rencana pembelajaran semester (RPS) atau istilah lain.

(2) Rencana pembelajaran semester (RPS) atau istilah lain sebagaimana dimaksud pada ayat (1) ditetapkan dan dikembangkan oleh dosen secara mandiri atau bersama dalam kelompok keahlian suatu bidang ilmu pengetahuan dan/atau teknologi dalam program studi.

(3) Rencana pembelajaran semester (RPS) atau istilah lain paling sedikit memuat:

a. Nama program studi, nama dan kode mata kuliah, semester, sks, nama dosen pengampu

b. Capaian pembelajaran lulusan yang dibebankan pada mata kuliah

c. c. Kemampuan akhir yang direncanakan pada tiap tahap pembelajaran untuk memenuhi capaian pembelajaran lulusan

d. Bahan kajian yang terkait dengan kemampuan yang akan dicapai metode pembelajaran

e. Waktu yang disediakan untuk mencapai kemampuan pada tiap tahap pembelajaran

f. Pengalaman belajar mahasiswa yang diwujudkan dalam deskripsi tugas yang harus dikerjakan oleh mahasiswa selama satu semester

g. Kriteria, indikator, dan bobot penilaian

h. Daftar referensi yang digunakan.

(4) Rencana pembelajaran semester (RPS) atau istilah lain wajib ditinjau dan disesuaikan secara berkala dengan perkembangan ilmu pengetahuan dan teknologi.

Metode pembelajaran yang digunakan dalam mata kuliah asuhan kebidanan nifas sudah sesuai dengan metode pembelajaran Student Centered Learning (SCL) yaitu Dalam menerapkan konsep Student Centered Learning, peserta didik diharapkan sebagai peserta aktif dan mandiri dalam proses belajarnya, yang bertanggungjawab dan berinisiatif untuk mengenali kebutuhan belajarnya, menemukan sumber-sumber informasi untuk dapat menjawab kebutuhanya, membangun serta mempresentasikan kebutuhan serta sumber-sumber yang ditemukan. Hasil Penelitian dan Pembahasan tentang pelaksanaan penerapan metode pembelajaran SCL pada mata kuliah Asuhan Kebidanan lbu Nifas di Program Studi Kebidanan STIKes Maharani Malang.

Pelaksanaan proses pembelajaran berlangsung dalam bentuk interaksi antara dosen, mahasiswa, dan sumber belajar dalam lingkungan belajar tertentu. Proses pembelajaran di setiap mata kuliah dilaksanakan sesuai Rencana Pembelajaran Semester (RPS) dan metode pembelajaran apa yang dapat dipilih dalam pelaksanaan pembelajaran. Ada 4 (empat) hal temuan pada tahap pelaksanaan yaitu (1) Pelaksanaan pembelajaran sudah sesuai dengan RPS atau silabus yang telah disusun atau direncanakan, (2) Pelaksanaannya sesuai dengan dengan sintak metode terpilih yaitu sintak dari berbagai metode SCL dalam RPP sudah sesuai dengan dengan kerangka konsep atau kajian teoritik dan sudah di adaptasikan sesuai dengan situasi dan kondisi. (3) Prosedur pelaksanaan pembelajaran pada tahap awal, tahap inti dan tahap akhir pembelajaran. Untuk implementasinya metode SCL yaitu terimplementasi pada tahap inti pembelajaran yaitu penerapan metode SGD (small group discussion) dan Role playing atau bermain peran. (4) Berbasis pada makna atau manfaat dari penerapan metode Student Centered Learning (SCL).

Ada 4 (empat) hal temuan pada tahap pelaksanaan yaitu:

1. Pelaksanaan pembelajaran sudah sesuai dengan RPS atau silabus yang telah disusun atau direncanakan.

2. Pelaksanaannya sesuai dengan dengan sintak metode terpilih yaitu sintak dari berbagai metode SCL dalam RPP sudah sesuai dengan dengan kerangka konsep atau kajian teoritik dan sudah di adaptasikan sesuai dengan situasi dan kondisi.

3. Prosedur pelaksanaan pembelajaran pada tahap awal, tahap inti dan tahap akhir pembelajaran. Untuk implementasinya metode SCL yaitu terimplementasi pada tahap inti pembelajaran yaitu penerapan metode SGD (small group discussion) dan Role playing atau bermain peran.

4. Berbasis pada makna atau manfaat dari penerapan metode Student Centered Learning (SCL).

Dalam pelaksanaan penerapan metode Student Centered Learning (SCL) pada mata kuliah asuhan kebidanan Ibu nifas di Program Studi Kebidanan STIKes Maharani Malang, masih belum terlaksana semuanya 
dikarenakan masih perlu menggunakan metode ceramah dari Dosen untuk menjelaskan konsep dasar teori Asuhan Ibu Nifas, yang mana mahasiswa masih perlu mendapatkan penjelasan konsep dasar dari Dosen. Pelaksanaan penerapan metode pembelajaran SCL (Student Centered Learning) sebagaimana tercantum dalam Peraturan Menteri Riset, Teknologi Dan Pendidikan Tinggi Republik Indonesia Nomor 44 Tahun 2015 Tentang Standar Nasional Pendidikan Tinggi pasal 13 yaitu:

(1) Pelaksanaan proses pembelajaran sebagaimana dimaksud dalam Pasal 10 ayat (2) huruf (c) berlangsung dalam bentuk interaksi antara dosen, mahasiswa dan sumber belajar dalam lingkungan belajar tertentu. (2) Proses pembelajaran di setiap mata kuliah dilaksanakan sesuai Rencana

Pembelajaran Semester (RPS) atau istilah lain dengan karakteristik sebagaimana dimaksud dalam Pasal 11 dan dinyatakan pada Pasal 14 yaitu: "Metode pembelajaran sebagaimana dinyatakan pada ayat (2) yang dapat dipilih untuk pelaksanaan pembelajaran mata kuliah meliputi: diskusi kelompok, simulasi, studi kasus, pembelajaran kolaboratif, pembelajaran kooperatif, pembelajaran berbasis proyek, pembelajaran berbasis masalah, atau metode pembelajaran lain,yang dapat secara efektif memfasilitasi pemenuhan capaian pembelajaran lulusan."

Proses pelaksanaan pembelajaran wajib dilakukan secara sistematis dan terstruktur melalui berbagai mata kuliah dengan beban belajar yang terukur dan menggunakan metode pembelajaran yang efektif sesuai dengan karakteristik mata kuliah. Hasil Penelitian dan Pembahasan Tentang Evaluasi hasil belajar mahasiswa dengan menggunakan metode pembelajaran Student Centered Learning (SCL) pada mata kuliah Asuhan Kebidanan lbu Nifas di Program Studi Kebidanan STIKes Maharani Malang.

Dalam tahapan evaluasi pembelajaran dilakukan beberapa standar penilaian pembelajaran mengenai bagaimana proses penilaian dan hasil belajar mahasiswa yang mencakup beberapa hal yaitu prinsip penilaian, teknik dan instrument penilaian, mekanisme penilaian, pelaksanaan penilaian dan pelaporan penilaian. Pada tahap evaluasi pembelajaran ditemukan keragaman jenis evaluasi yaitu:
a. Kehadiran atau presensi
b. UTS (ujian tengah semester)
c. UAS (ujian akhir semester)
d. Tugas
e. Praktikum

Jenis instrument evaluasi yaitu:
1. Penilaian Sikap

2. Penilaian Kinerja:

1) Presentasi makalah

2) Roleplay

3. Assesment praktikum

4. Pembuatan video praktikum

Dalam melaksanakan evaluasi pembelajaran sebagaimana tercantum dalam Peraturan Menteri Riset, Teknologi dan Pendidikan Tinggi Republik Indonesia Nomor 44 Tahun 2015 Tentang Standar Nasional Pendidikan Tinggi yaitu Standar Penilaian Pembelajaran.

Pasal 19 :

(1) Standar penilaian pembelajaran merupakan kriteria minimal tentang penilaian proses dan hasil belajar mahasiswa dalam rangka pemenuhan capaian pembelajaran lulusan.

(2) Penilaian proses dan hasil belajar mahasiswa sebagaimana dimaksud pada ayat (1) mencakup:
a. Prinsip penilaian
b. Teknik dan instrumen penilaian
c. Mekanisme dan prosedur penilaian
d. Pelaksanaan penilaian
e. Pelaporan penilaian
f. Kelulusan mahasiswa
Pasal 20:

1) Prinsip penilaian sebagaimana dimaksud dalam Pasal 19 ayat (2) huruf (a) mencakup prinsip edukatif, otentik, objektif, akuntabel, dan transparan yang dilakukan secara terintegrasi.

2) Prinsip edukatif sebagaimana dimaksud pada ayat merupakan penilaian yang memotivasi mahasiswa agar mampu:

a. memperbaiki perencanaan dan cara belajar.

b. meraih capaian pembelajaran lulusan.

3) Prinsip otentik sebagaimana dimaksud pada ayat (1) merupakan penilaian yang berorientasi pada proses belajar yang berkesinambungan dan hasil belajar yang mencerminkan kemampuan mahasiswa pada saat proses pembelajaran berlangsung.

4) Prinsip objektif sebagaimana dimaksud pada ayat (1)

5) merupakan penilaian yang didasarkan pada standar yang disepakati antara dosen dan mahasiswa serta bebas dari 
pengaruh subjektivitas penilai dan yang dinilai.

6) Prinsip akuntabel sebagaimana dimaksud pada ayat (1) merupakan penilaian yang dilaksanakan sesuai dengan prosedur dan kriteria yang jelas, disepakati pada awal kuliah, dan dipahami oleh mahasiswa.

7) Prinsip transparan sebagaimana dimaksud pada ayat (1) merupakan penilaian yang prosedur dan hasil penilaian dan dapat diakses oleh semua pemangku kepentingan.

Pasal 21:

1) Teknik penilaian sebagaimana dimaksud dalam Pasal 19 ayat (2) huruf $b$ terdiri atas observasi, partisipasi, unjuk kerja, tes tertulis, tes lisan, dan angket.

2) Instrumen penilaian sebagaimana dimaksud dalam Pasal 19 ayat (2) huruf $b$ terdiri atas penilaian proses

3) dalam bentuk rubrik dan/atau penilaian hasil dalam bentuk portofolio atau karya desain.

4) Penilaian sikap dapat menggunakan teknik penilaian observasi.

5) Penilaian penguasaan pengetahuan, keterampilan umum, dan keterampilan khusus dilakukan dengan memilih satu atau kombinasi dari berbagi teknik dan instrumen penilaian sebagaimana dimaksud pada ayat (1) dan ayat (2).

6) Hasil akhir penilaian merupakan integrasi antara berbagai teknik dan instrument penilaian yang digunakan.

Pasal 22 :

1) Mekanisme penilaian sebagaimana dimaksud dalam Pasal 19 ayat (2) huruf $\mathrm{c}$, terdiri atas:

a. Menyusun, menyampaikan, menyepakati tahap, teknik, instrumen, kriteria, indikator dan bobot penilaian antara penilai dan yang dinilai sesuai dengan rencana pembelajaran.

b. Melaksanakan proses penilaian sesuai dengan tahap, teknik,instrumen, kriteria, indikator, dan bobot penilaian yang memuat prinsip penilaian sebagaimana dimaksud dalam Pasal 20.

c. Memberikan umpan balik dan kesempatan

untuk mempertanyakan hasil penilaian kepada mahasiswa

d. Mendokumentasikan penilaian proses dan hasil belajar mahasiswa secara akuntabel dan transparan.

2) Prosedur penilaian sebagaimana dimaksud dalam Pasal 19 ayat (2) huruf $\mathrm{c}$ mencakup tahap perencanaan, kegiatan pemberian tugas atau soal, observasi kinerja, pengembalian hasil observasi, dan pemberian nilai akhir.

3) Prosedur penilaian pada tahap perencanaan sebagaimana dimaksud pada ayat (2) dapat dilakukan melalui penilaian bertahap dan/atau penilaian ulang.

Pasal 23:

1) Pelaksanaan penilaian sebagaimana dimaksud dalam Pasal 19 ayat (2) huruf $d$ dilakukan sesuai dengan rencana pembelajaran.

2) Pelaksanaan penilaian sebagaimana dimaksud ayat (1) dapat dilakukan oleh:

a. Dosen pengampu atau tim dosen pengampu

b. Dosen pengampu atau tim dosen pengampu dengan mengikutsertakan mahasiswa.

c. Dosen pengampu atau tim dosen pengampu dengan mengikutsertakan pemangku kepentingan yang relevan.

Dalam penelitian ini membahas bagaimana perencanaan, pelaksanaan dan evaluasi penerapan metode pembelajaran Student Centered Learning (SCL) pada mata kuliah asuhan kebidanan lbu nifas di Program Studi Kebidanan STIKes Maharani Malang, yang mana dalam hal perencanaan terdapat penyusunan RPS (Rencana Pembelajaran Semester) dan RPP (Rencana Pelaksanaan Pembelajaran) yang mana di dalamnya terdapat berbagai metode pembelajaran yang digunakan, termasuk metode CTJ (Ceramah Tanya Jawab), SGD (Small Group Discussion), PBL (Problem Based Learning) serta Role play (bermain peran). Dalam pelaksanaan penerapan metode Student Centered Learning (SCL) pada mata kuliah asuhan kebidanan Ibu nifas di Program Studi Kebidanan STIKes Maharani Malang, masih belum terlaksana semuanya dikarenakan masih perlu menggunakan metode ceramah dari Dosen untuk menjelaskan konsep dasar teori Asuhan Ibu Nifas, yang mana mahasiswa masih perlu mendapatkan penjelasan konsep dasar dari Dosen. Setelah melakukan perencanaan dan pelaksanaan penerapan metode Student 
Centered Learning (SCL), maka hasil dari evaluasi didapatkan bahwa penerapan metode SCL itu efektif karena lebih membuat mahasiswa aktif dan dalam proses pelaksanaanya tidak.

\section{Kesimpulan Dan Saran}

Kesimpulan

Penelitian ini bertujuan untuk mengetahui implementasi metode pembelajaran Student Centered Learning (SCL) pada mata kuliah asuhan kebidanan ibu nifas di Program Studi Kebidanan STIKes Maharani Malang, Berdasarkan pembahasan dan analisis yang telah dilakukan sebelumnya, maka dapat diambil kesimpulan bahwa implementasi penerapan metode Student Centered Learning (SCL) pada mata kuliah asuhan kebidanan ibu nifas yang melalui tiga tahapan yaitu (1) Tahap Perencanaan Pembelajaran (2) Tahap Pelaksanaan Pembelajaran dan (3) Tahap Evaluasi Pembelajaran.

Dalam tahap perencanaan pembelajaran diketahui bahwa PJMK (Penanggung Jawab Mata Kuliah) Asuhan Kebidanan Ibu Nifas telah menyusun silabus atau RPS (Rencana Pembelajaran Semester) pada saat rapat koordinasi dengan tim pengajar sebalum proses belajar mengajar dilaksanakan, kemudian dalam tahap pelaksanaan proses pembelajaran, sudah dilaksanakan sesuai dengan silabus atau RPS (Rencana Pembelajaran Semester) yang telah disusun dan disepakati bersama tim pengajar. Dalam mata kuliah asuhan kebidanan ibu nifas masih ada beberapa metode yang tercantum dalam silabus atau RPS (Rencana Pembelajaran Semester) yang menggunakan metode ceramah Tanya Jawab (CTJ) yang mana dosen yang lebih aktif dibandingkan mahasiswa dikarenakan dalam hal ini dosen berperan untuk menjelaskan materi konsep dasar mengenai asuhan ibu nifas dan dalam pelaksanaan pembelajaran ada beberapa penerapan metode Student Centered Learning (SCL) yang diterapkan dalam mata kuliah asuhan kebidanan ibu nifas yaitu metode Small Group Discussion (SGD), Problem Based Learning (PBL), Role play dan demonstrasi yang dilaksanakan dalam bentuk praktikum di laboratorium, dimana mahasiswa aktif dan mandiri dalam melakukan praktikum di laboratorium bahkan saling melakukan penilaian antar mahasiswa. Selanjutnya pada tahap evaluasi pembelajaran dilakukan penilaian yaitu ada beberapa hal yang terkait dengan teknik penilaian menggunakan tes tulis dalam bentuk ujian tengah semester dan ujian akhir semester, penilaian praktikum dalam bentuk assessment di laboratorium dan nilai penugasan penyusunan makalah yang terkait dengan kasus asuhan kebidanan pada ibu nifas untuk di presentasikan dan di diskusikan bersama di kelas.

Saran

Dalam tahap proses pembelajaran, diharapkan dosen pengajar menyusun silabus dan rencana pelaksanaan pembelajaran lebih menerapkan materi pembelajaran dengan berbagai metode pembelajaran Student Centered Learning (SCL). Dalam tahap pelaksanaan pembelajaran diharapkan dosen pengajar dapat memberikan materi baik di kelas maupun laboratorium sesuai dengan jadwalyang telah disusun dalam silabus dan pada tahap evaluasi pembelajaran dalam memberikan penilaian atau assessment dalam mekanisme penilaian akhir pembelajaran diharapkan lebih objektif. Untuk mahasiswa diharapkan lebih mampu menguasai dan memahami penerapan dari berbagai metode pembelajaran Student Center Learning (SCL) sehingga mahasiswa dapat mengembangkan kreativitas dan kemampuan berfikir kritis untuk memecahkan masalah dan mahasiswa diharapakan lebih aktif dalam proses pembelajaran serta mahasiswa memiliki kemampuan untuk mengembangkan potensi dirinya dalam hal mencari atau menggali pengetahuan dan

menerapkan ketrampilan dalam bidang ilmu kebidanan, khususnya dalam memberikan asuhan kebidanan pada ibu nifas.

\section{Daftar Pustaka}

Dewajani,S.2008. Materi Pelatihan SCL , Pembelajaran Student Centered Learning. Yogyakarta

Herdiansyah, Haris. 2010. Metodologi Penelitian Kualitatif untuk IImu-IImu Sosial. Jakarta: Salemba Humanika.

Kurdi, Fauziah.2009. Forum Kependidikan,Volume 28, Nomor 2. FKIP Unsri.

Miles,M.B.Huberman.A,M.1987.Quality Data Analysis.A Sourcebook of New Method.Beverly Hills:Sage Publication

Moleong J.Lexy.(2015).Metodologi Penelitian Kualitatif. Bandung: PT. Remaja Rosdakarya.

Permenristek Dikti RI No. 44 tahun 2014 Tentang Standar Nasional Perguruan Tinggi.

Satori Djam'an, Komariah Aan, 2014. Metodologi Penelitian Kualitatif. Bandung: CV Alfabeta

Sugiyono. 2010. Metode Penelitian 
Pendidikan Pendekatan Kuantitaf, Kualitatif, dan R\&D. Bandung: Alfabeta

Sumani, Mukhlas.2011.Belajar dan

Pembelajaran.Bandung: PT.Remaja Rosda Karya.

Syaiful, B.Djamarah.2008. Psikologi Belajar. Jakarta: PT.Rineka Cipta.

Wiriatmaja (2005). Pendekatan Penelitian Kualitatif. Bandung: Remaja Rosdakarya 